Mohamed Sabah Abdul Wahab BDS, (Master student)

\author{
Abdulhameed N. Aldabagh \\ BDS., MSc , PhD (Lec.)
}

Abdulsattar Salim Mahmood

BDS, MSc, PhD, (Lec.)

\section{Healing Assessment of Oral Mucosal Wounds Using Erbium, Chromium: Yttrium-Scandium-Gallium-Garnet Laser Versus Scalpel Blades}

\author{
Department of Oral and Maxillofacial Surgery \\ College of Dentistry, University of Mosul \\ Department of Oral and Maxillofacial Surgery \\ College of Dentistry, University of Mosul \\ Department of Oral and Maxillofacial Surgery \\ College of Dentistry, University of Mosul
}

\begin{abstract}
الخلاصة

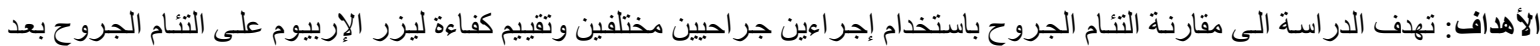

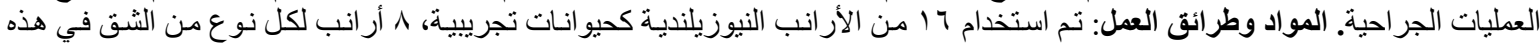

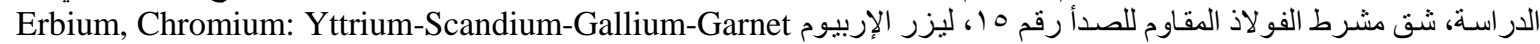

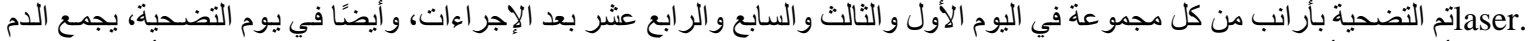

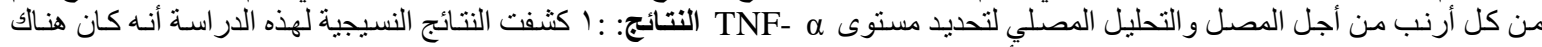

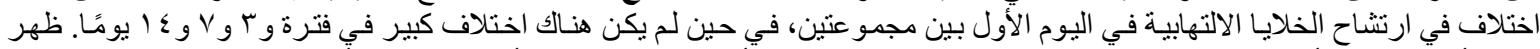

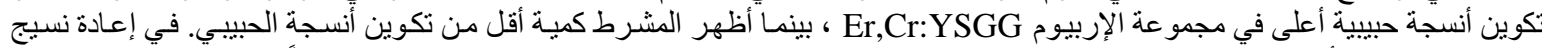

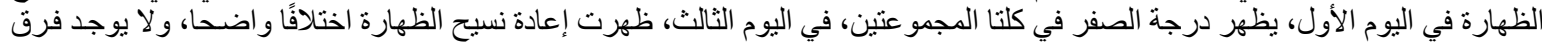

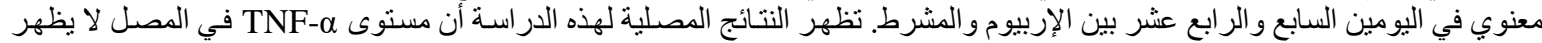

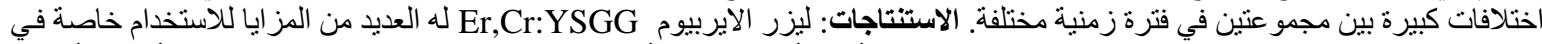

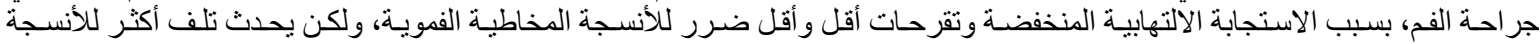

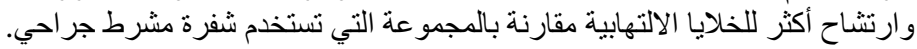

\begin{abstract}
Aims : The study aims to compare wound healing histologically and serologically by using two different surgical procedures and to evaluate the efficiency of the Er,Cr:YSGG laser on wound healing after surgical procedures. Materials and Methods : Sixteen New Zealand rabbits were used as experimental animals. The animals were divided into two groups: group I and group II, each group consisted of 8 rabbits. In group I; stainless steel scalpel blade NO.15 was used for making the incision, in group II Er, Cr: YSGG laser was used for making the incision. Two rabbits were sacrificed from each group at the 1st ,3rd ,7th and 14th days after procedures. On the day of sacrificial blood was collected from each rabbit for serum and serological analysis to determine serum level of TNF- $\alpha$. Results : 1:Histological findings of this study revealed that there was a significant difference in inflammatory cells infiltration at 1 st day between the two groups, while there was no significant difference at 3rd , 7th and 14th day periods. Granulation tissue formation appeared higher in erbium group, while scalpel blade incision showed less amount of granulation tissue formation. In reepithelialization at 1st day all section shows nil score in both groups, at 3rd day re-epithelization appeared significant difference, and no significance difference at 7 th and 14th days between erbium and scalpel blade. 2: Serological findings of this study shows that TNF- $\alpha$ level in serum have no significant differences between two groups at different time periods. Conclusions : Er,Cr:YSGG laser has numerous benefits for use particularly in oral surgery, due to low inflammatory reaction and less ulceration and smallest damage of the oral mucosal tissue, while more inflammatory cell infiltration occurs in comparison with group that used surgical scalpel blade.
\end{abstract}

Keywords: Er,Cr:YSGG laser, scalpel Blade, Tumor necrosis factor- $\alpha$, Histometric analysis . 
Abdul Wahab MS., Aldabaghan AN., Mahmood AS. Healing Assessment of Oral Mucosal Wounds Using Erbium, Chromium: Yttrium-Scandium-Gallium-Garnet Laser Versus Scalpel blades. Al-Rafidain Dent J. 2020;20(2):244-256.

DOI: 10.33899/rden.2020.127183.1036 C2020, College of Dentistry, University of Mosul Received: 23/5/2020 Sent to Referees: 30/5/2020 Accepted for Publication: 5/7/2020 This is an open access article under the CCBY4.0 license (http://creativecommons.org/licenses/by/4.0/).

\section{INTRODUCTION}

Wound define as breakdown in the normal continuity of the covering skin and/or mucosa; the loss of epithelial barrier, with or without disruption of underlying connective tissue (dermis, fascia and muscles), wounds occurred due to external damage ${ }^{(1-5)}$. The wound healing process is a complex pathophysiological mechanism that includes a cascade of coordinated inflammatory and proliferative events $^{(6)}$.

Surgical scalpels are fundamental tools to make soft tissue incisions ${ }^{(7)}$. The problems of using scalpel blade are pain, bleeding specially in highly vascular lesion and in a patient with bleeding disorders ${ }^{(8)}$. Many laser systems units are alternative to surgical knife blade on surgeries involving oral soft and hard tissues ${ }^{(9)}$.

The erbium laser first developed in 1990 and then came to the dental market and get approval from the Food and Drug Administration (FDA)to use on human being in $1997^{(10)}$. The performance of the laser is based on peak absorption rates of each laser wavelength. With erbium laser has an affinity for $(\mathrm{H} 2 \mathrm{O})$ particles, which makes them able to cut hard tissue as well as soft tissue ${ }^{(11)}$.
The biomarkers are biological indicator substances, the specific biomarkers can be identified by diagnostic tests, imaging technologies and other measurement devices of an individual's health status ${ }^{(12)}$. Researches have shown many mediators and cellular events happened within the wound healing that can be served as biomarkers. Neutrophils, ,Natural Killer Cell ,Macrophages, platelets and fibroblasts release cytokines molecules including Tumor necrosis factor- $\alpha(\mathrm{TNF}-\alpha)^{(13)}$.

\section{$\underline{\text { Aims of Study }}$}

- Is to compare wound healing under two different surgical procedures.

- To evaluate the efficiency of the erbium laser device on wound healing after surgical procedures.

\section{MATERIALS AND METHODS}

Sixteen healthy male New Zealand rabbits aged between 3 and 4 months and weight between 1.25 and $1.5 \mathrm{~kg}$ were used. They were retained in animal house at standard environment, and the animals were kept at a temperature of $30 \pm 5 \circ \mathrm{C}$ and all they received same amount of nutrition, so the outcome of wound healing be same in all rabbits .

All experimental procedures operating on rabbits followed the animal care protocol to 
prevent any health problems and to promote efficiency.

\section{Animal grouping}

The animals were randomly assigned into two experimental groups according to the types of incision. Each group consisted of 8 animals; two animals were euthanized at $1^{\text {st }}$ day, $3^{\text {rd }}$ Days , $7^{\text {th }}$ Days, and $14^{\text {th }}$ Days' time intervals.

Experimental Group I: Stainless steel surgical blade(No.15) wound incision. In this group incision was made by scalpel blade on buccal mucosa of the rabbits.

Experimental Group II: Er, Cr: YSGG laser wound incision (Waterlase MD, Biolase Technology, SanRamon, CA) in this group incision was made by Er, Cr: YSGG laser on buccal mucosa of the rabbits.

\section{Surgical procedure}

All surgical procedures were performed under supervision of two experienced surgeons, one in Oral and maxillofacial (Laser Specialist) and other in Veterinary Surgery and they followed a standardized protocol that used in Mosul University/ College of Dentistry/Department of Oral and Maxillofacial Surgery so as not to induce the surgical trauma during operation.
The rabbits were subjected to dissociative anesthesia by intramuscular administration of Ketamine with Xylazine Hydrochloride (0.6 ml) per one kilogram. After anesthesia, the surgical field in the oral cavity was disinfected by Chlorhexidine Gluconate $\% 0.2$ as a topical antiseptic.

Each incision had made with size of $5 \mathrm{~mm}$ length and $2 \mathrm{~mm}$ depth. The position of each incision was in a mid-space of diastema area between the angle of a mouth and mesial surface of posterior teeth.

All wounds were left opened.

All experimental animals did not take any type of analgesics or antibiotics postoperative .

\section{Erbium, Chromium: Yttrium-Scandium-}

\section{Gallium-Garnet laser parameter:}

The Er, Cr:YSGG laser apparatus (Fig.1) wavelength was $2780 \mathrm{~nm}$, power $1.5 \mathrm{~W}, 9 \%$ water, $12 \%$ air spray, pulse duration (140 ms), repetition rate $(30 \mathrm{~Hz})$, energy density of (300 $\mathrm{mJ} / \mathrm{cm} 2$ ) with a contact mode (S-mode), tip type (MT-4), and hand-piece type (MD Gold Handpiece).

The setting of laser device was according to manufacturer recommendation. The laser device calibrated by the dealer (BIOLASE Service-ERBIL) before the study. 


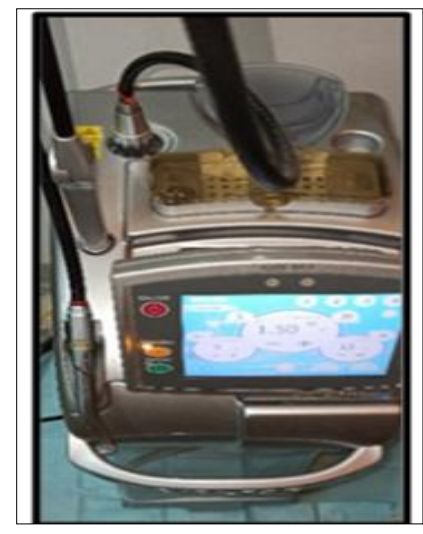

Figure (1): Er, Cr:YSGG laser apparatus

\section{$\underline{\text { Serological test }}$}

After the rabbit had been sacrificed by using a sharp knife, the first few drops left to prevent hemolysis. Blood collection tubes are disposable and non-endotoxin(Purified E.coli endotoxin, Gram negative bacteria and Grampositive bacteria induce cytokines secretion by whole blood cultures (WBC's) and this will affect on level of TNF- $\alpha$ ). The tube put in a holder in upright position for serum preparation which allows samples to clot for 2 hours at room temperature before centrifugation for 15 mins at $3000 \times \mathrm{g}$ at $\left(25^{\circ} \mathrm{C}\right)$. The serum collected by micropipette and gathering in Eppendorf tube, labeling each tube and freeze it in $\left(-20^{\circ} \mathrm{C}\right)$ for assaying the level of TNF- $\alpha$ by ELISA test.

\section{Histological analysis}

The tissue was immediately dissected from buccal mucosa and introduced in a solution of 10\% Neutral Buffered Formalin. The specimens were harvested, and sections of five microns in series were sliced and stained by hematoxylin and eosin for histological analysis. The histometric measurements depending on criteria in (Tables 1,2, and 3) were done under a light microscope connected to a digital camera at magnification of $\mathrm{x} 10$ and $\mathrm{x} 40$.

Table (1) : Criteria of inflammatory cells infiltration (scoring): ${ }^{(24,25)}$

1 Nil :No inflammatory cells seen in the field of operation (X10).

2 Mild : inflammatory cells present in feww numbers, less than $1 / 2$ of the field (X10).

3 Moderate: inflammatory cells could be seen in more than $1 / 2$ of the field (X10).

4 Severe or abundant : inflammatory cells present in huge numbers, more than $3 / 4$ of the field (X10).

Table (2): Criteria for amount granulation tissue formation (Scoring): ${ }^{(24,25)}$

\begin{tabular}{ll}
\hline 1 & Absent of granulation tissue formation in wound \\
2 & Quantity of granulation tissue formation in the wound gap is scanty \\
3 & Amount of granulation tissue formation is moderate in t tissue. \\
4 & Total amount of granulation tissue formation in the wound is profound. \\
\hline
\end{tabular}


Table (3): Criteria of Re-epithelization (Scoring): ${ }^{(26)}$

0 Re- epithelization at the edge of the wound.

1 Re-epithelization $n$ covering less than half of the wound.

2 Re-epithelization covering more than half of the wound.

3 Re-epithelization covering the entire wound, irregular thickness .

4 Re-epithelization covering the entire wound, normal thickness.

\section{$\underline{\text { Statistical analysis }}$}

The current study used non-parametric utest (Mann-Whitney), because its comparative study between two groups and data not followed specific disruption.

\section{RESULTS}

All the rabbits survived during experimental procedures.

\section{Histological findings}

At Day one after procedure

The scalpel group appeared moderate number of inflammatory cells infiltration present in slides section, see (Figures 2, 3, and Table 4). While, the Er,Cr:YSGG laser incision shows huge number of inflammatory cells infiltration seen in the field of incision see (Figures 4 ,10, and Table 5). Granulation Tissue Formation mainly absent in both the scalpel Er,Cr:YSGG laser incision. Reepithelialization evaluation in the scalpel and Er,Cr:YSGG groups we noticed that reepithelialization presents only at the edge of wound in both groups, see (Figures 2,3, and $5)$.

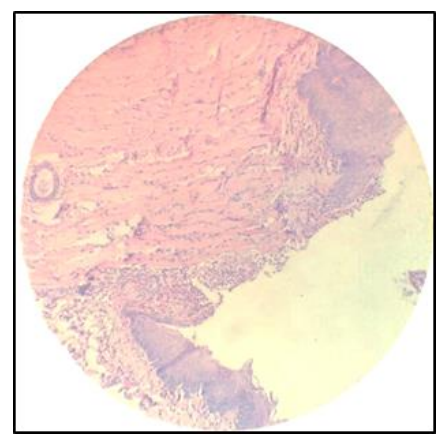

Figure (2): Histological section of scalpel incision at 1st day.

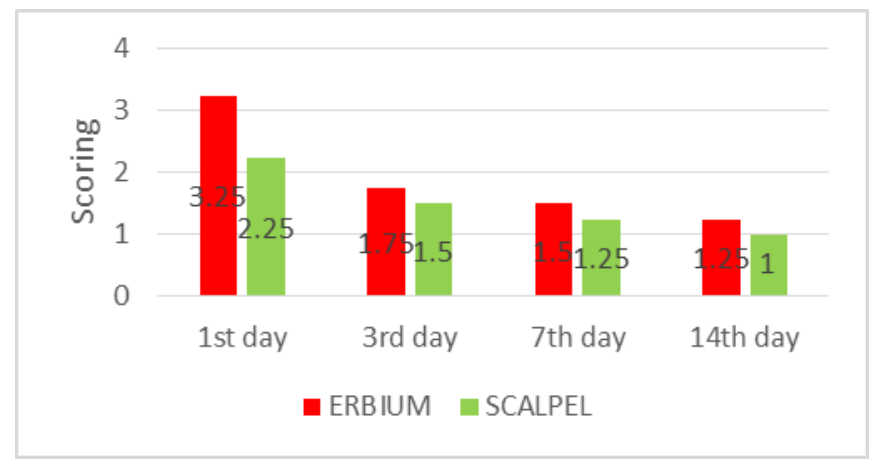

Figure (3): Inflammatory Cells Infiltration Scoring at $1^{\text {st }}, 3^{\text {rd }}, 7^{\text {th }}$, and $14^{\text {th }}$ Days after Incisions 
Table (4): Mean of scores of inflammatory cells infiltration, granulation tissue formation and reepithelialization for scalpel blade incision groups.

\begin{tabular}{cccc}
\hline $\begin{array}{c}\text { Euthanized } \\
\text { day of } \\
\text { scalpel } \\
\text { group }\end{array}$ & $\begin{array}{c}\text { I.C.I. } \\
\text { means } \\
\text { of } \\
\text { scores }\end{array}$ & $\begin{array}{c}\text { G.T.F. } \\
\text { means } \\
\text { of } \\
\text { scores }\end{array}$ & $\begin{array}{c}\text { Epithelization } \\
\text { means of } \\
\text { scores }\end{array}$ \\
\hline $1^{\text {st }}$ & 2.25 & 1.5 & 0 \\
$3^{\text {rd }}$ & 1.5 & 2 & 0.5 \\
$7^{\text {th }}$ & 1.25 & 1.5 & 2.75 \\
$14^{\text {th }}$ & 1 & 1.5 & 4 \\
\hline
\end{tabular}

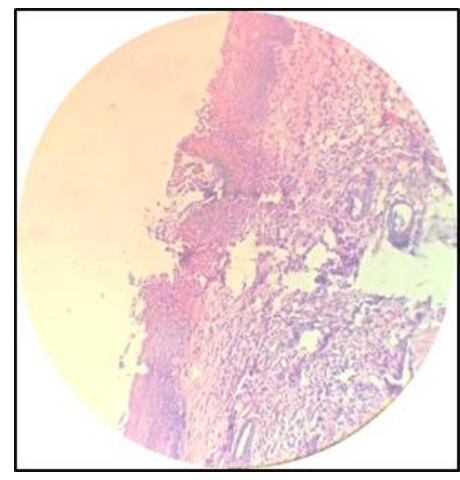

Figure (4): Histological section of erbium laser incision at 1st day

Table (5): Mean of scores of inflammatory cells infiltration, granulation tissue formation and reepithelialization for Erbium laser (Waterlaser MD; BIOLASE, SanRamon, CA) incision groups.

\begin{tabular}{cccc}
\hline $\begin{array}{c}\text { Euthanized } \\
\text { day of } \\
\text { erbium } \\
\text { group }\end{array}$ & $\begin{array}{c}\text { I.C.I. } \\
\text { means } \\
\text { of } \\
\text { scores }\end{array}$ & $\begin{array}{c}\text { G.T.F. } \\
\text { means } \\
\text { of } \\
\text { scores }\end{array}$ & $\begin{array}{c}\text { Epithelization } \\
\text { means of } \\
\text { scores }\end{array}$ \\
\hline $1^{\text {st }}$ & 3.25 & 1.5 & 0 \\
$3^{\text {rd }}$ & 1.75 & 1.5 & 1.5 \\
$7^{\text {th }}$ & 1.5 & 1.75 & 2.75 \\
$14^{\text {th }}$ & 1.25 & 2 & 3.5 \\
\hline
\end{tabular}

* I.C.I. = Inflammatory cells infiltration

* G.T.F. $=$ Granulation Tissue Formation

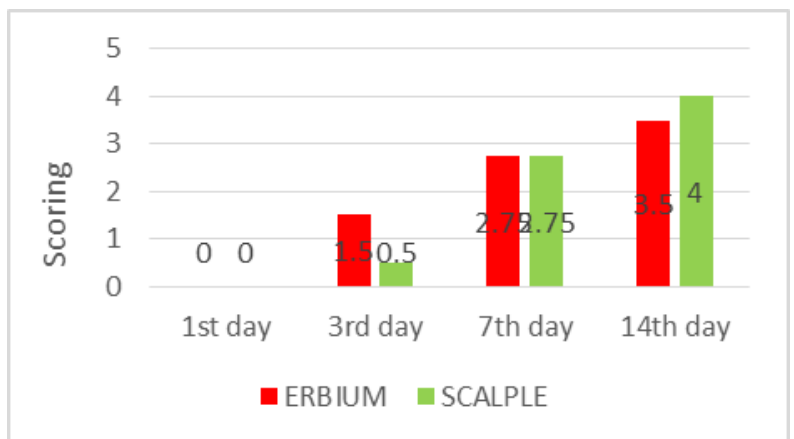

Figure (5): Re-epithelization of oral mucosa Scoring at 1st ,3rd ,7th , and 14th Days after Incisions 


\section{At Third Day after procedure}

In scalpel slides display the number of inflammatory cells infiltration present in few quantities, see (Figures 6, 10, and Table 4). While ,the Er,Cr:YSGG laser incision group section reveled moderate amount of Inflammatory cells infiltration present in tissue section (Figures 7, 10, and Table 5). Granulation Tissue Formation for scalpel group showed small amount of granulation tissue formation (Figures 4, and 9).In Er,Cr:YSGG laser incision group in some sections was absent, while on other side of section appear scanty. Re-epithelialization evaluation of wound in scalpel groups present only at the edge of the wound (Figures 4, and 8). Half slides of the Er,Cr:YSGG laser group show us the re-epithelialization covering less than half of the wound. On the other half of slides display re-epithelialization covering more than half of the wound.

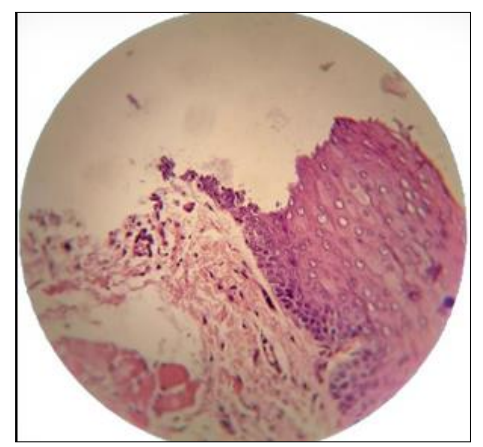

Figure (6): Histological section of scalpel incision at $3^{\text {rd }}$ day.

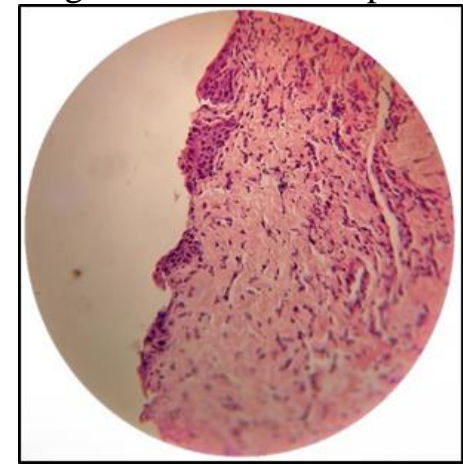

Figure (7): Histological section of erbium laser incision at $3^{\text {rd }}$ day.

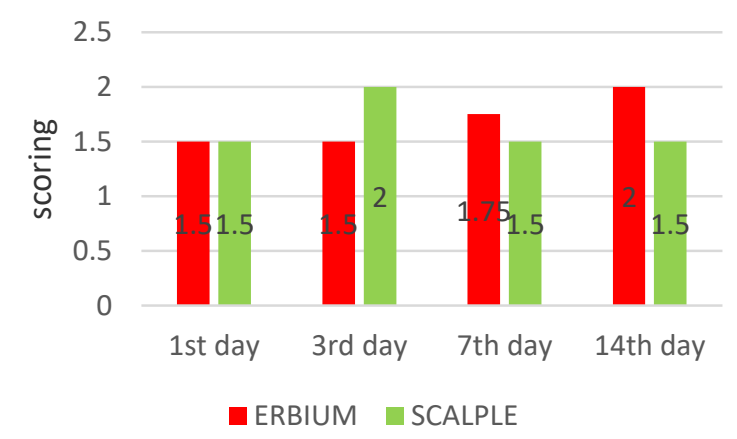

Figure (8): Granulation Tissues Formation Scoring at 1st ,3rd ,7th ,and 14th Days after Incisions. 


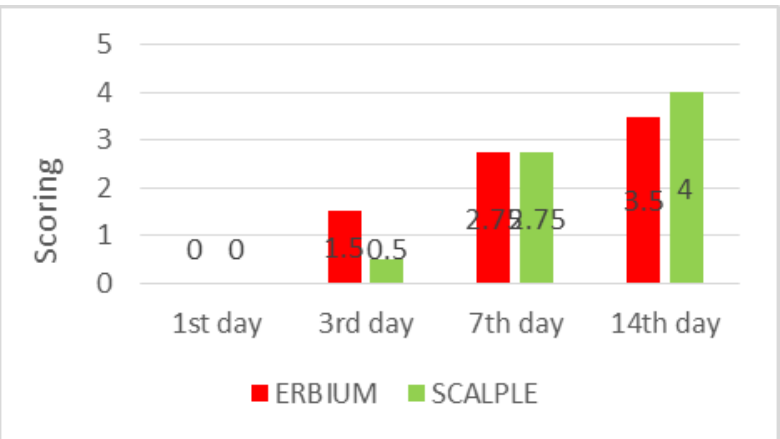

Figure (9): Re-epithelization of oral mucosa Scoring at 1st ,3rd ,7th , and 14th Days after Incisions

\section{At One Week after procedure}

In scalpel group appear inflammatory cells infiltration present in few numbers and in some section appeared Nil ,see (Figures 10,9 and Table 4). While, Er,Cr:YSGG laser section that tell us few number inflammatory cells infiltration see (Figures 7,10, and Table 5). Granulation Tissue Formation in both groups is little. Re-epithelialization in scalpel and Er,Cr:YSGG groups we noticed that reepithelialization covering the entire wound, with irregular thickness after seven days, see (Figures 6, and 7).

\section{At Fourteen days later}

The scalpel slides display no inflammatory cells infiltration present in slide section(Figures 8, and 10). While, Er,Cr:YSGG laser incision group section reveled scores between mild to nil Inflammatory cells infiltration present in tissue section. Granulation tissue formation scored small amount in scalpel and scanty in erbium . Re-epithelialization scalpel groups showed re-epithelialization covering the entire wound with normal thickness of epithelium(Figures 8, and 12).

Half slides of the Er,Cr:YSGG laser group showed the re-epithelialization covering the entire wound, some slide appeared with regular thickness other histological section display irregular thickness of epithelium (Figures 9 and 12) .

\section{Serological findings}

Serological test is performed under supervision of Biochemistry Specialist in RNA lab at Mosul city by Using ELISA .The mean of each group according to the score's was recorded by Microplate reader at $450 \mathrm{~nm}$ wavelength for serum that collected at first day and at 3, 7, and 14 days' time periods. TNF- $\alpha$ level appeared no significant differences between two groups at different time interval (Tables 6, 7) . 


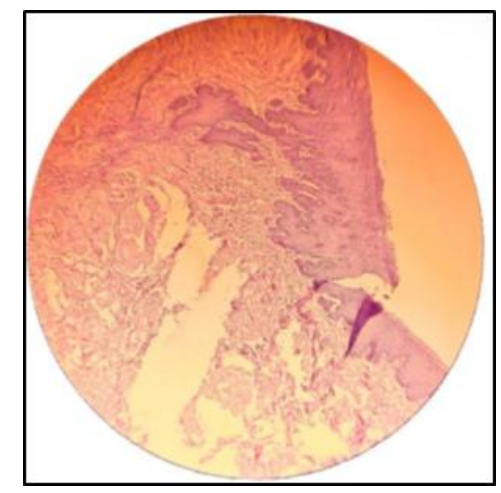

Figure (10): Histological section of scalpel incision at $7^{\text {th }}$ day.

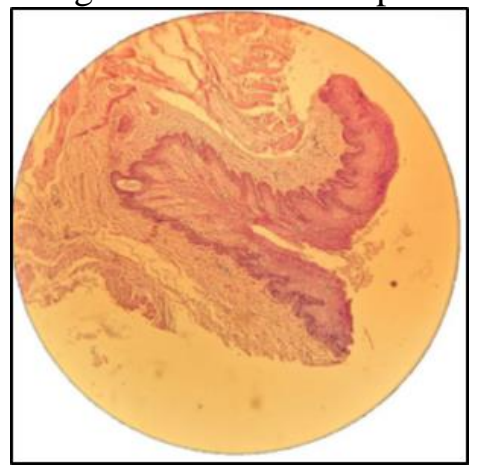

Figure (11): Histological section of erbium laser incision at $7^{\text {th }}$ day

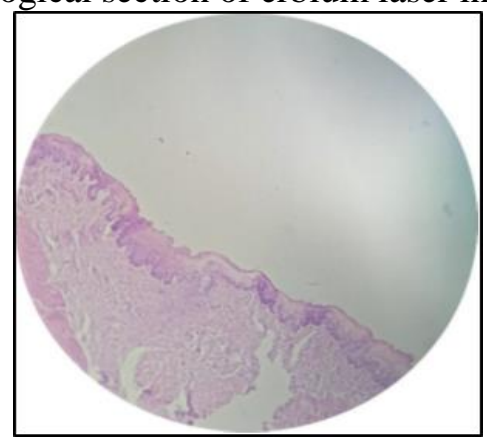

Figure (12): Histological section of scalpel incision at $14^{\text {th }}$ day

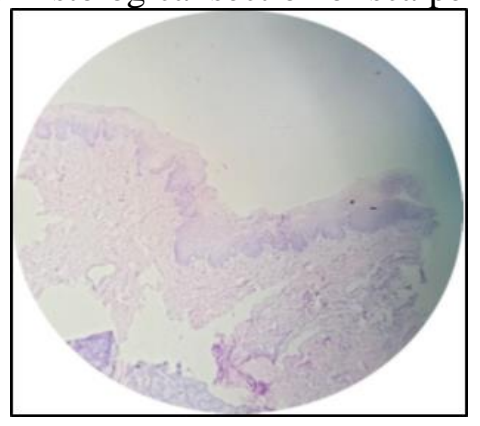

Figure (13): Histological section of erbium laser incision at $14^{\text {th }}$ day. 
Table (6): P-value for inflammatory cells infiltration, granulation tissue formation and reepithelialization at different period.

\begin{tabular}{cccc}
\hline $\begin{array}{c}\text { Euthanized } \\
\text { day }\end{array}$ & $\begin{array}{c}\text { Inflammatory Cells } \\
\text { Infiltration p-value }\end{array}$ & $\begin{array}{c}\text { Granulation tissue } \\
\text { formation P-value }\end{array}$ & $\begin{array}{c}\text { Re-epithelialization } \\
\text { P-value }\end{array}$ \\
\hline $\mathbf{1}^{\text {st }}$ day & $0.040^{*}$ & 1.000 & 1.000 \\
$\mathbf{3}^{\text {rd }}$ day & 0.495 & 0.127 & 0.61 \\
$\mathbf{7}^{\text {th }}$ day & 0.495 & 0.495 & 1.000 \\
$\mathbf{1 4}^{\text {th }}$ day & .0317 & 0.127 & 0.127 \\
\hline
\end{tabular}

P-value $\leq 0.05 /\left(^{*}\right)$ Significant different

Table (7):Mean of score for Level of TNF- $\alpha$ at different time interval

\begin{tabular}{ccc}
\hline $\begin{array}{c}\text { Time } \\
\text { interval }\end{array}$ & $\begin{array}{c}\text { TNF- } \alpha \text { Level } \\
\text { for Scalpel } \\
\text { group }\end{array}$ & $\begin{array}{c}\text { TNF- } \boldsymbol{\alpha} \text { Level } \\
\text { for Erbium } \\
\text { group }\end{array}$ \\
\hline $\mathbf{1}^{\text {st }}$ Day & 0.052 & 0.0515 \\
$\mathbf{3}^{\text {rd }}$ Day & 0.0515 & 0.0575 \\
$\mathbf{7}^{\text {th }}$ Day & 0.0515 & 0.058 \\
$\mathbf{1 4}^{\text {th }}$ Day & 0.0545 & 0.0565 \\
\hline
\end{tabular}

\section{DISCUSSION}

During current research the clinical observation of incisions that was made by laser device showed many advantages on soft tissue surgery which included: precision, a relatively great coagulation of blood, with minimum swelling and no need for suture, these benefits were accepted with Protasio, Galvao (14)on their findings.

The histological part of this study found minimal histological damage and cell injury occurred with scalpel, less epithelial damage ,minimal wound gap and less collagen denaturation when surgical scalpel blade used if we compared it with wounds produced by laser and these come parallel with result of Azevedo, Delgado et al. found on their researches ${ }^{(15,16)}$

Despite the fact that, the erbium laser induces less thermal damage because of water and air spray coolant, minimal epithelial edge damage and tissue artifacts. For this reason, decent and quick re-epithelization of wound margin at site of incision in compared with other types of laser that do not use water during incision .This is accepted with CercadilloIbarguren, España-Tost (17), but scalpel still gave us better re-epithelization this totally agreement with Perussi, Pavone (18). The energy from erbium laser beam was converted into local thermal energy, and this thermal energy generates a massive expansion in the 
target water chromophore. The energy causes the water molecules to be heated into steam, causing micro explosions in soft tissue resulted ablation of thin layers of soft tissue which cause strains and fractures the surrounding extracellular collagen matrix ${ }^{(19)}$.

Amaral, de Avila et al. 2015 in their study discovered that wound healing will be faster when surgical scalpel blade is used for removing the oral lesions. And Azevedo, Monteiro et al.2016 found the scalpel blade creates smallest amount of tissue damage in comparison with other equipment's that used in their study. In addition ,Cayan, Hasanoglu Erbasar et al.2019 discovered that when scalpel blade used . Post-surgery showed the wound healing occurred faster in scalpel blade in compared with diode group when remove the same type of oral lesion. In histological part and clinical observation of wounds in present study showed healing of incisions produced by scalpel much faster than other groups and these come match with Amaral, Azevedo, et al. founds $(9,15,20)$.

\section{Serological test}

Cytokines level like TNF-alpha will be much higher in non-healing wound and wound with high inflammatory response due to these cytokines released be inflammatory cells like what Patel, Maheshwari (13), Shah, Omar ${ }^{(21)}$ found in their researches.

Gohel, Windhaber ${ }^{(22)}$ found in his study, that performed on chronic ulcer to analysis the relationship between level of cytokines like TNF- alpha and wound healing process, when blood sample is collected from patients suffered of chronic ulcer, found was poor relationship between cytokines and ulcer healing is consequential remains unknown.

El Ayadi, Herndon ${ }^{(23)}$ Observed the appearance of pro-inflammatory cytokines is significantly changed after burn injury, and the concentration of these cytokines alone or with respect to each other can be used to predict septic condition during healing.

\section{CONCLUSIONS}

Depending on results and statistical analysis in (Table 6), the scalpel blade has better healing process and decent cutting of tissue without effect on histological analysis of specimen, Histopathologic artifactual changes induced by Er,Cr:YSGG laser are insignificant but inflammation still here higher than scalpel incisions. This indicates that this laser system could be used for diagnostic as well as therapeutic applications if correct laser parameters and specific laser tip were used.

\section{REFERENCES}

1.Businaro R, Corsi M, Di Raimo T, Marasco S, Laskin DL, Salvati B, et al. Multidisciplinary approaches to stimulate wound healing. Ann N Y Acad Sci. 2016;1378(1):137-42.

2.Eming SA, Martin P, Tomic-Canic M. Wound repair and regeneration: mechanisms, signaling, 
and translation. Science translational medicine. 2014;6(265):265sr6.

3.Trott AT. Chapter 2 - Patient Evaluation and Wound Assessment. In: Trott AT, editor. Wounds and Lacerations (Fourth Edition). Philadelphia: W.B. Saunders; 2012. p. 4-9.

4.Lazarus GS, Cooper DM, Knighton DR Margolis DJ, Pecoraro RE, Rodeheaver G, et al. Definitions and guidelines for assessment of wounds and evaluation of healing. Archives of dermatology. 1994;130(4):489-93.

5.Kang MH, Kim BH. Oral Wound Healing Effects of Acai Berry Water Extracts in Rat Oral Mucosa. Toxicological research. 2018;34(2):97-102.

6.Iqbal A, Jan A, Wajid MA, Tariq S. Management of Chronic Non-healing Wounds by Hirudotherapy. World J Plast Surg. 2017;6(1):9-17.

7.Giovannini M, Ehmann K. Vibrational Cutting of Soft Tissue with Micro-serrated Surgical Scalpels. Procedia CIRP. 2016;45:199-202.

8.Ji Y, Yang K, Peng S, Chen S, Xiang B, Xu Z, et al. Kaposiform haemangioendothelioma: clinical features, complications and risk factors for Kasabach-Merritt phenomenon. The British journal of dermatology. 2018;179(2):457-63.

9.Amaral MB, de Avila JM, Abreu MH, Mesquita RA. Diode laser surgery versus scalpel surgery in the treatment of fibrous hyperplasia: a randomized clinical trial. International journal of oral and maxillofacial surgery. 2015;44(11):1383-9.
10. Tao S, Li L, Yuan H, Tao S, Cheng Y, He L, et al. Erbium Laser Technology vs Traditional Drilling for Caries Removal: A Systematic Review with Meta-Analysis. The journal of evidence-based dental practice. 2017;17(4):324-34.

11.Dionysopoulos D, Strakas D, KoliniotouKoumpia E, Koumpia E. Effect of Er,Cr:YSGG laser irradiation on bovine enamel surface during in-office tooth bleaching ex vivo. Odontology. 2017;105(3):320-8.

12.Kumar M, Sarin, S. K. . Biomarkers of diseases in medicine. Current Trends in Science. 2009;Platinum Jubilee Special 40317.

13.Patel S, Maheshwari A, Chandra A. Biomarkers for wound healing and their evaluation. Journal of wound care. 2016;25(1):46-55.

14.Protasio ACR, Galvao EL, Falci SGM. Laser Techniques or Scalpel Incision for Labial Frenectomy: A Meta-analysis. Journal of maxillofacial and oral surgery. 2019;18(4):4909.

15.Azevedo A-S, Monteiro L-S, Ferreira F, Delgado M-L, Garcês F, Carreira S, et al. In vitro histological evaluation of the surgical margins made by different laser wavelengths in tongue tissues. Journal of clinical and experimental dentistry. 2016;8(4):e388-e96.

16.Monteiro L, Delgado ML, Garces F, Machado M, Ferreira F, Martins M, et al. A histological evaluation of the surgical margins from human oral fibrous-epithelial lesions excised with $\mathrm{CO} 2$ 
laser, Diode laser, Er:YAG laser, Nd:YAG photomedicine, and laser surgery. laser, electrosurgical scalpel and cold scalpel. 2019;37(2):91-8.

Medicina oral, patologia oral y cirugia bucal. 21.Shah JM, Omar E, Pai DR, Sood S. Cellular 2019;24(2):e271-e80. events and biomarkers of wound healing.

17.Cercadillo-Ibarguren I, España-Tost A, Indian journal of plastic surgery : official Arnabat-Domínguez J, Valmaseda-Castellón E, publication of the Association of Plastic Berini-Aytés L, Gay-Escoda C. Histologic Surgeons of India. 2012;45(2):220-8.

evaluation of thermal damage produced on soft tissues by CO2, Er,Cr:YSGG and diode lasers. 22.Gohel MS, Windhaber RAJ, Tarlton JF, Medicina oral, patologia oral y cirugia bucal. 2010;15(6):e912-8.

18.Perussi LR, Pavone C, de Oliveira GJ, Cerri PS, Marcantonio RA. Effects of the Er,Cr:YSGG laser on bone and soft tissue in a rat model. Lasers in medical science. 2012;27(1):95-102.

Whyman MR, Poskitt KR. The relationship between cytokine concentrations and wound healing in chronic venous ulceration. Journal of Vascular Surgery. 2008;48(5):1272-7.

23.El Ayadi A, Herndon DN, Finnerty CC. 21 Biomarkers in Burn Patient Care. In: Herndon DN, editor. Total Burn Care (Fifth Edition): Elsevier; 2018. p. 232-5.e2.

19.Giannelli M, Formigli L, Bani D. 24.Gupta A, Kumar P. Assessment of the Comparative evaluation of photoablative efficacy of erbium: yttrium-aluminium-garnet histological state of the healing wound. Plast Aesthet Res. 2015;2:239-42.

and diode laser for the treatment of gingival hyperpigmentation. A randomized split-mouth clinical trial. Journal of periodontology. 2014;85(4):554-61.

20.Cayan T, Hasanoglu Erbasar GN, Akca G, Kahraman S. Comparative Evaluation of Diode Laser and Scalpel Surgery in the Treatment of Inflammatory Fibrous Hyperplasia: A SplitMouth Study. Photobiomodulation, 25.Sultana J, Molla M, Kamal M, Shahidullah M, Begum F, Bashar A. Histological differences in wound healing in Maxillofacial region in patients with or without risk factors. Bangladesh Journal of Pathology. 2009;24.

26.Sinha UK, Gallagher LA. Effects of steel scalpel, ultrasonic scalpel, $\mathrm{CO} 2$ laser, and monopolar and bipolar electrosurgery on wound healing in guinea pig oral mucosa. The Laryngoscope. 2003;113(2):228-36. 